\title{
Environmental Pollution in Pearl River Delta, China: Status and Potential Effects
}

\author{
F. Wang ${ }^{1 *}$ and R. J. Hao ${ }^{1}$ \\ ${ }^{1}$ State Key Joint Laboratory of Environmental Simulation and Pollution Control, School of Environment, Beijing Normal University, \\ Beijing, 100875, China
}

Received 13 April 2020; revised 11 May 2020; accepted 2 June 2020; published online 30 June 2020

\begin{abstract}
Rapid economic growth in the Pearl River Delta (PRD) region, south China, has resulted in severe pollution of the natural eco-environment since the reform and opening up. Of various sources for eco-environmental deterioration, the negative impact of environmental pollutants is a global concern. Large amounts of research on environmental pollution in the PRD have been accumulated, which allows us to conduct a fairly comprehensive assessment of the environment state of the PRD. This review examines environmental pollutions (e.g., heavy metals, organics) mainly in water, air, and soil. The general information of these pollutions on current levels, possible causes, and potential effects in PRD were reviewed. The study found that heavy metals had an increasing trend in PRD in recent decades, especially for $\mathrm{Cr}$. The sediments in coastal wetlands were significantly contaminated by Cd, Zn, and Ni. The levels of DDTs in various environmental media are of great concern. The discharge of industrial effluents and domestic sewage seemed to cause nutrient and heavy metal pollution in environmental media. Atmospheric emissions of gaseous and particulate pollutants have caused profound environmental and health implications. Growing public concern over the potential accumulation of heavy metals in soils could be owing to rapid urban and industrial development.
\end{abstract}

Keywords: environmental pollutions, Pearl River Delta, potential effects

\section{Introduction}

With the rapid development of industries, agriculture, and urbanization in China, a large number of pollutions without effecttive treatment were discharged into the environmental system, which has resulted in serious pollution to the environment (Jahn et al., 2011). The problem is even worse in urban areas, especially in urban agglomerations such as the Beijing-Tianjin-Hebei region, Pearl River Delta (PRD), and Yangtze River Delta. Thus, it's desired to conduct a fairly comprehensive assessment of the environmental pollution of the PRD.

The PRD metropolitan area has been one of the leading regions of China's urbanization and economy, whose social economic development mode has been known as 'the Pearl River Delta mode', and its urbanization rate exceeded $80 \%$. The rapid industrialization and urbanization of the PRD have brought with it dramatic land cover change. The PRD is one of the most agriculturally developed, fishery flourished, and industrially advanced regions in China, which has consequently created severe environmental stresses (Guangdong Statistical Yearbook, 2017). At the same time, the PRD region becomes a leading manufacturing center of the world. Industrial expansion in this region of Guangdong was characterized by the spread of industrial activities from hot spots in Guangzhou, Foshan, and

\footnotetext{
* Corresponding author. Tel.: +(86) 1058800156; fax: + (86) 1058800156. E-mail address: fengwang@mail.bnu.edu.cn (F. Wang).

ISSN: 2663-6859 print/2663-6867 online

(C) 2020 ISEIS All rights reserved. doi:10.3808/jeil.202000033.
}

Dongguan to widely distribute patches of industrial active districts, mostly in the seven newly agglomerate formed and urbanizing prefectural municipalities (Wong et al., 2002). To provide transportation communication between Guangzhou city and the municipal cities, a system of highways was built and a region road-network surfaced for the connection of the expanding municipal cities and their suburban areas as well as the patches of industrial districts, within their municipalities. Also, a network of power plants was built at its periphery (Zhang et al., 2011). With the rapid development of industries, agriculture and urbanization of coastal zone in PRD, a large amount of pollution without effective treatment was discharged, which have resulted in serious pollution to the environment. Fu et al. (2003) reported summarizes the published scientific data on POPs in the environment of the Pearl River Delta, including the levels of POPs in the air, water, soil, river and estuarine sediments, the marine organisms like fish and shellfish in this region. Guo et al. (2009) reviewed the occurrence, source diagnosis, and biological effect assessment of DDT and its metabolites in various environ-mental compartments of the Pearl River Delta, South China. Jahn et al. (2011) provided a systematic literature review and health risk assessment of particulate matter pollution in the megacities of the Pearl River Delta, China. Zhang et al. (2013) reviewed environmental and human exposure to persistent organic pollutants in the Pearl River Delta, South China. Therefore, as the extension of the previous study, the objections of this study is to conduct a comprehensive assessment of pollution in the environment (i.e., water, air, and soil) for the PRD, including the current status and potential effects. 


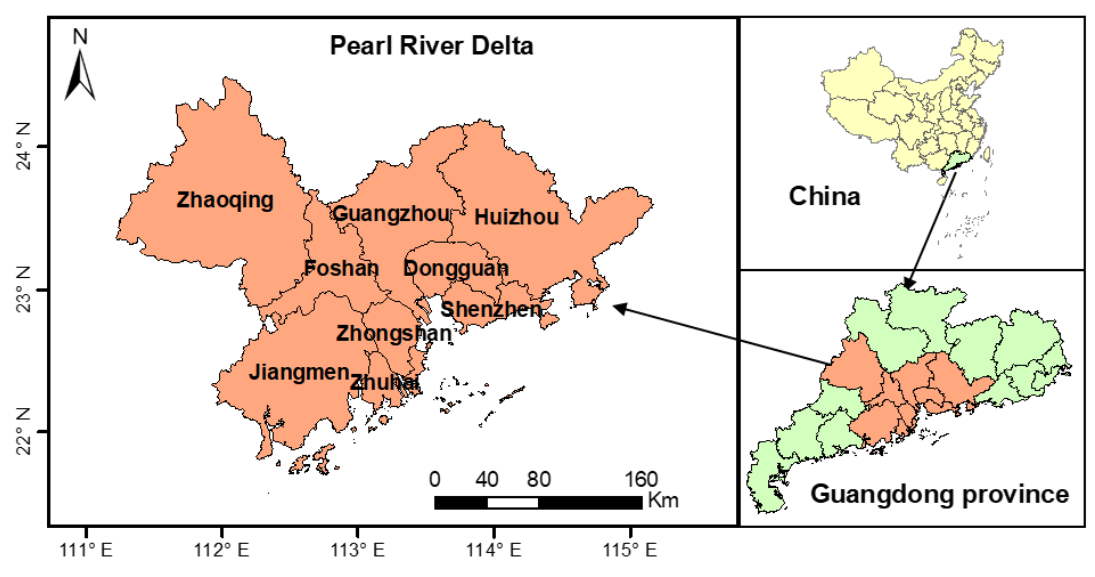

Figure 1. The Pearl River Delta.

\section{Overview of Pearl River Delta}

The PRD lies in the southeast of Guangdong province, China, and is close to the South China Sea $\left(21^{\circ} 27^{\prime} \mathrm{N} \sim 23^{\circ} 56^{\prime}\right.$ $\mathrm{N}$ and $111^{\circ} 59^{\prime} \mathrm{E} \sim 115^{\circ} 26^{\prime} \mathrm{E}$ ) (Figure 1). The Pearl River Delta belongs to the subtropical marine monsoon climate zone, characterized by abundant rainfall and warm environment; the average annual temperature is approximately $22{ }^{\circ} \mathrm{C}$ and the mean annual precipitation is $1,600 \sim 2,000 \mathrm{~mm}$. The main soil types are latosolic red soil and cultivated paddy soil. Forest and cropland comprise the dominant vegetation types, of which the main forest type is the subtropical monsoon evergreen broad-leaved forest. However, this native vegetation type has almost been eliminated by long-term disturbance from human activities.

Ranging a total area of $40,041 \mathrm{~km}^{2}$ with a population of 61.50 million people, $55.07 \%$ of the Guangdong province, the PRD covers nine municipalities in the Guangdong province: Dongguan, Foshan, Guangzhou, Huizhou, Shenzhen, Zhongshan, Zhuhai, and part of Jiangmen, Zhaoqing (Hills et al., 1998). Since the establishment of Chinese Opening Policies in 1978, it has been rapidly transforming from an agricultural area to one of the most important urban industrial regions of China. The main industries in the PRD region include electronics, textiles, paper making, and cement production. Since the late $19^{\text {th }}$ century, the PRD region of Guangdong has been turned into a leading manufacturing center, not only in China, but also in the world. In 2017, the gross domestic product (GDP) in the PRD reached 1190 billion U.S. dollars, over $10 \%$ of the Chinese total and more than $80 \%$ of the Guangdong province GDP (Guangdong Statistical Yearbook, 2017).

\section{Water Environmental Pollution}

Anthropogenic activities in the PRD have caused a deterioration of water quality over the past twenty years as a result of rapid urbanization and industrial development. Researchers proved the Parameters responsible for water quality variations in different River region were varies (Fan et al., 2010). For example water quality variations in North River region was main- ly related to organic related parameters ( $\mathrm{DO}$ and $\mathrm{COD}_{\mathrm{Mn}}$ ), inorganic nutrients $\left(\mathrm{NH}_{3}-\mathrm{N}\right.$ and $\mathrm{TP}$ ) and metal $\mathrm{Hg}$, in East River region, mainly related to organic related parameters $\left(\mathrm{BOD}_{5}\right)$ and inorganic nutrients $\left(\mathrm{NH}_{3}-\mathrm{N}\right.$ and $\left.\mathrm{TP}\right)$, in West River Region, mainly related to organic related parameters $\left(\mathrm{COD}_{\mathrm{Mn}}\right)$ and inorganic nutrients $\left(\mathrm{NH}_{3}-\mathrm{N}\right.$ and $\mathrm{TP}$ ) (Fan et al., 2010). Along the southeast coast, surface water heavily polluted areas are mainly distributed within or downstream of major manufacturing districts, intensive agricultural basins, and other industrial centers (Han and Currell, 2017). During the urban development process, urbanization and urban activities had a significant negative impact on the river water quality. Compared to the rural river water, urban river water was polluted more seriously (Ouyang et al., 2006). According to the researches, there is a positive correlation between the rapidity of urbanization and the pollution levels of the urban river (Ren et al., 2017). For example, the aquatic environments are subjected to contamination with various industrial chemicals from local industries (Chen et al., 2014). And impervious surface area has also been recognized as a key indicator of the effects of non-point runoff and water quality (Liu et al., 2012). Rivers in PRD are now facing great challenges because of heavy metal contamination, organics, nutrients and so on described as follows ( $\mathrm{Lu}$ et al., 2010; Clark et al., 2015).

\subsection{Heavy Metals}

There are widespread pollution and high contents of the heavy metals (e.g., $\mathrm{Cd}, \mathrm{Cr}, \mathrm{Cu}, \mathrm{Ni}, \mathrm{Pb}, \mathrm{As}, \mathrm{Hg}$, and $\mathrm{Zn}$ ) in the river and river sediments in PRD (Cai et al., 2011; Xiao et al., 2013). Table 1 presents the heavy metal concentrations in sediments from coastal areas of PRD. The total contents of the heavy metals $(\mathrm{Cd}, \mathrm{Cr}, \mathrm{Cu}, \mathrm{Ni}, \mathrm{Pb}$, and $\mathrm{Zn})$ in urban and rural rivers in the urbanization zone exceeded the soil background value (Xiao et al., 2013). And compared to rural river sites, urban river sites exhibited heavier pollution (Ouyang et al., 2006, Xiao et al., 2013) both in the surface sediment $(0 \sim 20$ $\mathrm{cm})$ and the bottom sediments $(21 \sim 50 \mathrm{~cm})$ (Li et al., 2013). Urban river sediments, especially the surface sediment layer $(0$ $\sim 10 \mathrm{~cm}$ ), exhibited higher metallic pollution levels (Zhang et 
Table 1. Heavy Metal Concentrations in Sediments from Coastal Areas of PRD (mg/kg.dw)

\begin{tabular}{llllllllll}
\hline Locations & $\mathrm{Cd}$ & $\mathrm{Cu}$ & $\mathrm{Cr}$ & $\mathrm{Hg}$ & $\mathrm{Ni}$ & $\mathrm{Pb}$ & $\mathrm{Zn}$ & $\mathrm{As}$ & Sources \\
\hline Daya Bay & $0.05 \sim 0.32$ & $2 \sim 49$ & $42 \sim 127$ & 0.09 & $11 \sim 31$ & $19 \sim 589$ & $53 \sim 117$ & - & $\mathrm{Li}$ et al., 2000 \\
Lingdingyang & $0.04 \sim 0.84$ & $3 \sim 100$ & $20 \sim 135$ & - & $8 \sim 54$ & $5 \sim 96$ & $32 \sim 289$ & $10.2 \sim 22.8$ Li et al., 2007 \\
West four PRE & - & $9 \sim 77$ & $60 \sim 102$ & - & $12 \sim 54$ & $16 \sim 62$ & $19 \sim 199$ & - & Wang et al., \\
$\begin{array}{l}\text { regions } \\
\text { Hailing Bay }\end{array}$ & $0.01 \sim 0.36$ & $1 \sim 59$ & $4 \sim 75$ & 0.08 & $1 \sim 43$ & $15 \sim 1088$ & $12 \sim 219$ & $2.2 \sim 20.3$ & Yu et al., 2010 \\
Zhanjiang & $\mathrm{Nd} \sim 0.45$ & $10 \sim 27$ & 68 & $0.03 \sim 0.17$ & $19 \sim 27$ & $18 \sim 68$ & $16 \sim 115$ & $11 \sim 16$ & Ye et al., 2012 \\
\hline
\end{tabular}

al., 2017). Major metal pollutants differ from region to region. There was widespread pollution and high enrichment of $\mathrm{Cu}$ in river sediments in Zhongshan City (Cai et al., 2011), and Cd, $\mathrm{Zn}$ and $\mathrm{Cu}$ were the primary metals in the Peal River sediments (Zhang et al., 2017). The sediments in coastal wetlands were significantly contaminated by $\mathrm{Cd}, \mathrm{Zn}$, and $\mathrm{Ni}$ with concentration ranges of $2.79 \sim 4.65,239.4 \sim 345.7$, and $24.8 \sim 122.1$ $\mathrm{mg} / \mathrm{kg}$, respectively (Li et al., 2007). Results showed that $\mathrm{Hg}$ was the most serious pollutant with high spatial variability in Foshan Waterway (Li et al., 2013). Metal pollutant concentration also changes with time. Research show that $\mathrm{Cr}$ had a significant increasing trend $(\mathrm{P}<0.05)$, As and $\mathrm{Cd}$ increased but not with statistical significance $(\mathrm{P}=0.10)$ and $\mathrm{Hg}$ and $\mathrm{Zn}$ trend a slightly increasing in the Shenzhen River during $1991 \sim 2006$ (Huang et al., 2012).

Wang et al. (2013) reviewed more than 90 articles on levels, distributions, and sources of heavy metals in sediments and organisms in coastal areas of South China and found that heavy metal levels were closely associated with local economic development (Wang et al., 2013). Cai et al. (2011) reported the potential ecological risk of metals to rivers were related to the land use patterns, in the order of manufacturing areas $>$ residential areas $>$ agriculture areas. Compared with rural river sediments, heavy metals were highly associated with the exchangeable and carbonate fractions in both urban and reclamation-affected river sediments, suggesting that anthropogenic activities mainly increased the active forms of metals (Zhang et al., 2017). Sediment organic matter and grain size might be important factors influencing the distribution profiles of these heavy metals (Xiao et al., 2013). The results of the principal component analysis show that the discharge of industrial wastewater is the most important polluting factor in the Foshan Waterway whereas domestic sewage, which contains a large amount of organic substances, accelerates metal deposition ( $\mathrm{Li}$ et al., 2013).

Heavy metal contamination has a great ecological risk for river ecosystems due to its environmental toxicity, abundance, and persistence. $\mathrm{Hg}$ and $\mathrm{Cd}$ had posed a high potential ecological risk to urban rivers and the ecological risk of metals was not eliminated along with the improvement in water quality (Cai et al., 2011). The potential ecological risk indices of rural river sediments were equal to those of urban river sediments, implying that the ecological health issues of the rivers in the undeveloped rural area should also be addressed (Xiao et al., 2013). The evaluation results of enrichment factors and potential ecological risk index indicate that the metal pollution in the surface and bottom sediments could pose a serious threat to the ecosystem (Li et al., 2013). Researchers found that the sediment in coastal wetlands of the Pearl River Estuary was no longer suitable for the current wetland utilization strategies (Li et al., 2007). Heavy metal pollution such as Arsenic and Mercury in water can affect freshwater fish ponds (Cheng et al., 2013) and aquaculture pond ecosystem (Cheng et al., 2011). High levels of heavy metals were found in biota from Ling Dingyang in Guangdong province. Mollusks had higher concentrations of heavy metals than other species. Human health risk assessments suggested that levels of heavy metals in some seafood from coastal areas of South China exceeded the safety limit (Wang et al., 2013). A significant level of $\mathrm{Pb}$ was found in tilapia at all locations (Leung et al., 2014). The hazard index values of all fish species were smaller than 1 for adults and children, indicating there was no health risk from the multiple metals via the ingestion of the freshwater fish for the inhabitants (Cheng et al., 2013).

\subsection{Pesticide}

The degree of trace organic contamination was, in general, more severe at stations situated along the west shores of the PRD than their counterparts in the east (Fung et al., 2005). Among the reported data for DDTs (Table 2), the highest concentration was found in Daya Bay in 1999 (range: 26.8 976 ng/L and mean: 188 ng/L) (Zhou et al., 2001). Another high concentration of $190 \mathrm{ng} / \mathrm{L}$ was detected in a sample from the Shenzhen River in 1994 (Yang et al., 1997). Other researchers have otherwise reported much lower levels of DDTs (Gan et al., 2009; Huang et al., 2010; Zhang et al., 2010). For example, concentrations of DDTs measured in riverine runoff of the PRD from March 2005 to February 2006 ranged between 1.08 and $19.6 \mathrm{ng} / \mathrm{L}$ with a mean of $3.89 \mathrm{ng} / \mathrm{L}$ (Gan et al., 2009). Few data on the occurrence of POPs in precipitation from the PRD are currently available. Levels of DDTs in precipitation from rural sites were lower than those from urban areas of Guangzhou (Huang et al., 2010). Compared with those detected in rural sites of Dongguan and Shunde, higher levels of DDT in precipitation from rural sites of Guangzhou (Yue et al., 2011). DDTs were also found in fishpond waters from rural areas of Dongguan and Shunde with an average of 1.46 and $0.69 \mathrm{ng} / \mathrm{L}$, respectively (Zhang et al., 2010). High concentrations of DDT observed in fishes collected from the Pearl River estuary (PRE) and Daya Bay (Guo et al., 2008).

A mass balance consideration indicated that riverine runoff is the major mode carrying organochlorine pesticides (OCPs) from the PRD to the coastal ocean, and the majority of OCPs 
is further dissipated to open seas (Guan et al., 2009). Bioconcentration was suggested to be responsible for the accumulation of OCPs and polybrominated biphenyl ethers (PBDEs) in the lower trophic organisms in the studied subtropical waters (Guo et al., 2008). A preliminary assessment showed that OC pesticide contamination in the PRD was particularly serious and might pose a threat to the health of the marine inhabitants (Fung et al., 2005). The accumulation of high levels of these pollutants in any of these compartments may exert adverse health effects on marine organisms and humans.

Table 2. Concentration of DDTs in Water Environmental

\begin{tabular}{lll}
\hline Location & Concentration $(\mathrm{ng} / \mathrm{L})$ & Sources \\
\hline Daya Bay & $26.8 \sim 976$ & Zhou et al., 2001 \\
Shenzhen River & 190 & Yang et al., 1997 \\
PRD & $1.08 \sim 19.6$ & Gan et al., 2009 \\
Dongguan & 1.46 & Zhang et al., 2010 \\
Shunde & 0.69 & Zhang et al., 2010 \\
Lingding Bay & $2.6 \sim 115.6$ & Kang et al., 2000 \\
Xijiang River & $5.0 \sim 16.6$ & Mai et al., 2001 \\
Lajia Island & 9.5 & Fang et al., 2001 \\
Beijing Pier & 72.6 & Fang et al., 2001 \\
\hline
\end{tabular}

\subsection{Antibiotics}

Ten antibiotics belonging to three groups (macrolides, fluoroquinolones, and sulfonamides) were detected in the eight outlets with concentrations ranging from 0.7 to $127 \mathrm{ng} / \mathrm{L}$ in the PRD and Pearl River Estuary (PRE) (Xu et al., 2013). The annual mass loadings of antibiotics from the PRD to the PRE and coast were 193 tons with 102 tons from the fluoroquinolone group. Antibiotics such as quinolones and sulfonamides were found widely distributed in the cultured fishes and the higher levels of veterinary antibiotics (VAs) were found in freshwater fishes than marine fishes (He et al., 2016). Certain antibiotics were detected in industrial wastewater and domestic sewage at considerably higher concentrations than those measured in the river water, indicating important sources of antibiotic contamination (Zhang et al., 2017). The spatial distribution of the five Fluoroquinolone also exhibited a close relationship with the intensity of local human activity (Zhang et al., 2017). Riverine runoff also plays an important role in the transportation of antibiotics contaminants from terrestrial sources to the open ocean (Xu et al., 2013). Risk assessment showed that most of these antibiotics showed various ecological risks to the relevant aquatic organisms, in which ofloxacin (OFL), erythromycin (ETM) and ciprofloxacin (CIP) posed high ecological risks to the studied aquatic environments (Xu et al., 2013).

\subsection{Endocrine Disrupting}

Endocrine-disrupting chemicals (EDCs) were found to be widely present at rather high concentrations in the urban riverine water of Guangzhou (Peng et al., 2008). Sedimentary organic carbon is an important factor in controlling the EDCs and the spatial distribution of EDCs in riverine sediments was related to the discharge of domestic and industrial wastewater along the rivers (Gong et al., 2011). Pharmaceuticals and personal care products (PPCPs) in the urban riverine water of Guangzhou originated mainly from random discharge and/or leakage of municipal wastewater (Peng et al., 2008). PPCPs interfere mainly with the sexual functions in animals, causing feminization, imposex, decreased fecundity, and developmental abnormalities which should attract particular attention.

\subsection{Nutrients}

Coastal eutrophication is a recognized phenomenon, and scientific investigation of this human disturbance has progressed for a few decades. The concentration of nutrients decreased slightly in the past decade but still stayed at a high level. The concentration of DIN was general above $0.30 \mathrm{mg} / \mathrm{L}$ in the estuary, and more than $0.50 \mathrm{mg} / \mathrm{L}$ for the most part. The concentration of phosphate was generally about $0.015 \mathrm{mg} / \mathrm{L}$ except for the area near Shenzhen Bay. The ratio of N:P was generally high, and it was higher in the north than in the south. Turbidity and phosphate may be the main two limiting factors for algal bloom in the estuary (Huang et al., 2003). The nutriaents mainly came from domestic sewage, industrial wastewater, agriculture fertilizer, and marine culture in the Pearl River estuary (Huang et al., 2003). Nonpoint source pollution (with nitrate and related compounds) due to agriculture is a major issue affecting groundwater (Han et al., 2016). The focus of controlling water pollution is controlling pollution sources and reducing the discharge of wastewater to streams and shallow aquifers (Han et al., 2016). The eutrophication had an influence on transportation and transformation of contaminants in the aquatic environment, which including potential key factors, such as biomass dissolving functions, a staying period in waters, sediment embedding, and structures of food net (Huang et al., 2003).

\subsection{Other Organics}

Alkylphenol octylphenol (OP) and nonylphenol (NP) were detected in river surface water and sediments in the runoff outlets of the PRD (Chen et al., 2014). Mean concentrations of OP and NP in surface water during the dry season ranged from 810 to $3366 \mathrm{ng} / \mathrm{L}$ and 85.5 to $581 \mathrm{ng} / \mathrm{L}$, respectively, and those in sediments ranged from 14.2 to $95.2 \mathrm{ng} / \mathrm{g} \cdot \mathrm{dw}$ and 0.4 to $3.0 \mathrm{ng} / \mathrm{g}$. $\mathrm{dw}$, respectively. Much higher concentrations were detected in the dry season than those in the wet season. High concentrations of NP and OP were found in the Humen outlet, likely due to high levels of domestic and industrial wastewater discharges (Chen et al., 2014). The results of the ecological risk assessment indicated that the current levels of NP and OP pose a significant risk to the relevant aquatic organisms in Pearl River Delta (Chen et al., 2014). The highest levels of six Phthalate esters (PAEs) were observed both in water and sediments collected from the PRD's six main estuaries (Li et al., 2016). Seasonal variation and spatial distribution of PAEs concentrations both in water and surface sediments. In detail, the highest concentration of total PAEs was detected in summer and the lowest levels were in winter. The spatial distribution of PAEs concentrations is mainly related to the location. The highest concen- 

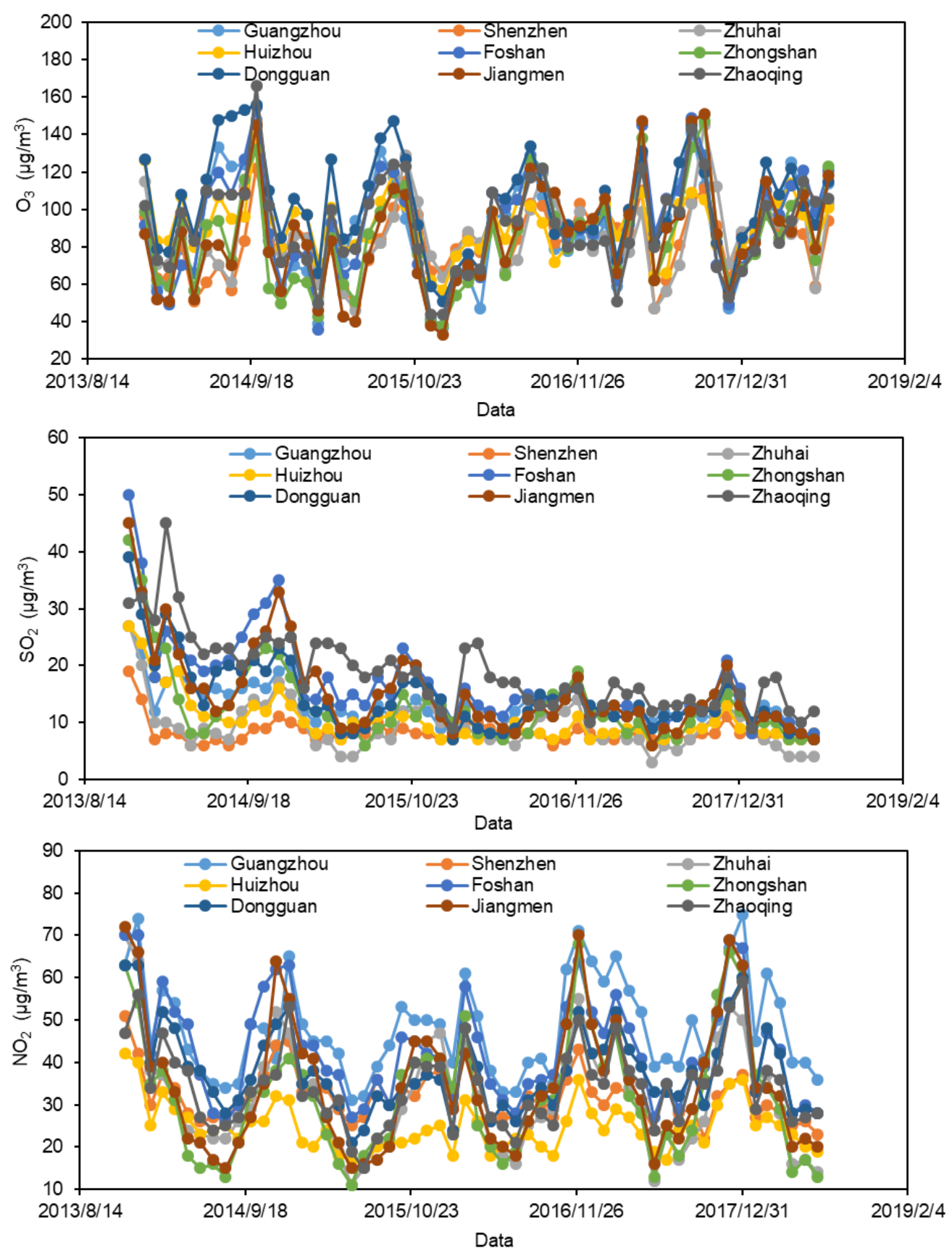

Figure 2. The concentration of $\mathrm{O}_{3}, \mathrm{SO}_{2}$, and $\mathrm{NO}_{2}$ in PRD. (Data source: China National Environmental Monitoring Centre: http://www.cnemc.cn/).

tration of PAEs was found in the downstream of emerging industrial cities such as Zhongshan and Jiangmen (Li et al., 2016). Moreover, densely populated, heavy industrial, and commercial cities such as Guangzhou and Dongguan also discharged a great amount of PAEs (Li et al., 2016). The three fluoroquinolones were already detected in fish samples, and the concentrations were higher in liver tissues than those in muscle tissues (He et al., 2012). Luckily, there is little health risk posed by the PAEs congeners to the residents in the PRD at the con- centrations observed in water samples (Li et al., 2016), and no relevant immediate harm to the coastal population of Guangdong via the consumption of marine aquaculture fish (He et al., 2012).

\section{Air Environmental Pollution}

\subsection{Ozone, $\mathrm{SO}_{2}, \mathrm{NO}_{x}$}

Atmospheric emissions of gaseous and particulate pollu- 

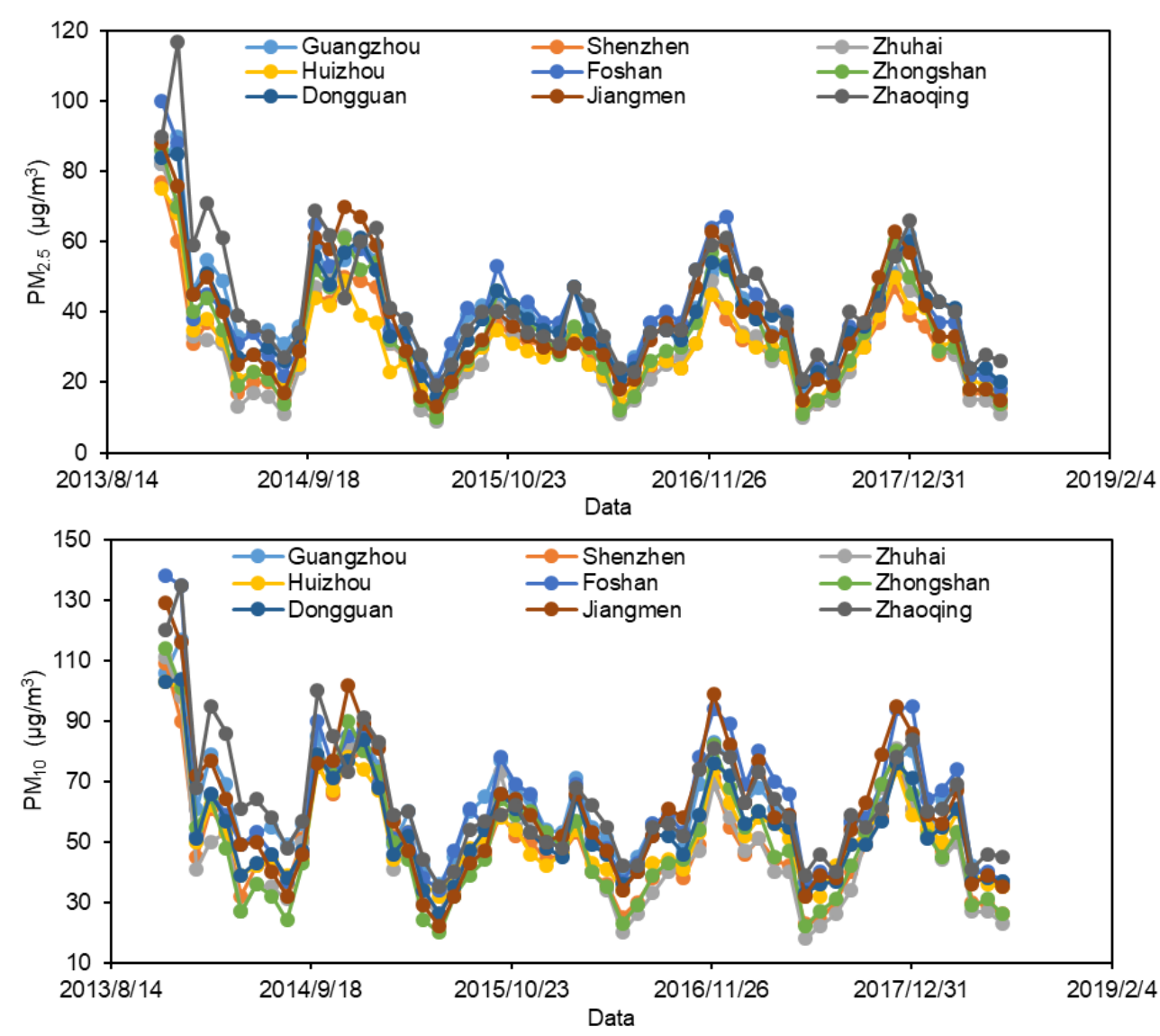

Figure 3. The concentration of $\mathrm{PM}_{2.5}$ and $\mathrm{PM}_{10}$ in PRD. (Data source: China National Environmental Monitoring Centre: http://www.cnemc.cn/).

Table 3. Overview of Air Pollution in the Sites during PRD 2013 2018

\begin{tabular}{|c|c|c|c|c|c|c|c|c|c|c|}
\hline & & GZ & $\mathrm{SZ}$ & $\mathrm{ZH}$ & $\mathrm{HZ}$ & FS & $\mathrm{ZS}$ & DG & $\mathrm{JM}$ & ZQ \\
\hline \multirow[t]{3}{*}{ AQI } & $\min$ & 47 & 28 & 25 & 37 & 40 & 26 & 47 & 25 & 42 \\
\hline & mean & 74 & 55 & 59 & 58 & 73 & 64 & 73 & 69 & 72 \\
\hline & $\max$ & 120 & 103 & 109 & 101 & 132 & 114 & 114 & 117 & 151 \\
\hline \multirow[t]{3}{*}{$\mathrm{PM}_{2.5}\left(\mathrm{mg} / \mathrm{m}^{3}\right)$} & $\min$ & 18 & 11 & 9 & 13 & 18 & 10 & 16 & 13 & 19 \\
\hline & mean & 40 & 30 & 30 & 30 & 40 & 34 & 39 & 37 & 43 \\
\hline & $\max$ & 90 & 77 & 82 & 75 & 100 & 86 & 85 & 88 & 117 \\
\hline \multirow[t]{3}{*}{$\mathrm{PM}_{10}\left(\mathrm{mg} / \mathrm{m}^{3}\right)$} & $\min$ & 36 & 23 & 18 & 32 & 34 & 20 & 26 & 22 & 35 \\
\hline & mean & 61 & 48 & 49 & 52 & 62 & 50 & 54 & 60 & 63 \\
\hline & $\max$ & 117 & 109 & 111 & 103 & 138 & 114 & 104 & 129 & 135 \\
\hline \multirow[t]{3}{*}{$\mathrm{SO}_{2}\left(\mathrm{mg} / \mathrm{m}^{3}\right)$} & $\min$ & 8 & 6 & 3 & 6 & 8 & 6 & 7 & 6 & 9 \\
\hline & mean & 13 & 8 & 9 & 10 & 17 & 13 & 14 & 15 & 19 \\
\hline & $\max$ & 27 & 19 & 27 & 27 & 50 & 42 & 39 & 45 & 45 \\
\hline \multirow[t]{3}{*}{$\mathrm{CO}\left(\mathrm{mg} / \mathrm{m}^{3}\right)$} & $\min$ & 0.70 & 0.49 & 0.51 & 0.49 & 0.61 & 0.55 & 0.58 & 0.53 & 0.68 \\
\hline & mean & 0.95 & 0.86 & 0.80 & 0.78 & 0.91 & 0.97 & 0.88 & 0.92 & 1.00 \\
\hline & $\max$ & 1.37 & 1.43 & 1.51 & 1.18 & 1.48 & 1.51 & 1.28 & 1.63 & 1.55 \\
\hline \multirow[t]{3}{*}{$\mathrm{NO}_{2}\left(\mathrm{mg} / \mathrm{m}^{3}\right)$} & $\min$ & 31 & 22 & 11 & 16 & 26 & 11 & 21 & 15 & 15 \\
\hline & mean & 48 & 32 & 32 & 25 & 43 & 32 & 38 & 35 & 34 \\
\hline & $\max$ & 75 & 51 & 70 & 42 & 70 & 68 & 63 & 72 & 59 \\
\hline \multirow[t]{3}{*}{$\mathrm{O}_{3}\left(\mathrm{mg} / \mathrm{m}^{3}\right)$} & $\min$ & 37 & 47 & 46 & 57 & 36 & 38 & 51 & 33 & 44 \\
\hline & mean & 90 & 83 & 85 & 92 & 92 & 84 & 103 & 86 & 91 \\
\hline & $\max$ & 148 & 122 & 147 & 140 & 155 & 147 & 156 & 151 & 166 \\
\hline
\end{tabular}

*Data source: China National Environmental Monitoring Centre: http://www.cnemc.cn/ 
tants have caused profound environmental and health implications in recent years. Urbanization increases more surfaceozone concentration the night time (Wang et al., 2009). As shown in Figure 2 and Table 3, the maximum hourly $\mathrm{O}_{3}$ concentration in Guangzhou, Foshan, Zhongshan, and Shenzhen varied from 300 to $370 \mathrm{mg} / \mathrm{m}^{3}$. Areas with main $\mathrm{O}_{3}$ concentrations increase to coincide with the areas of increased temperature and decreased wind speed, and the timing of maximum ozone concentration increase occurs a few hours later than maximum temperature increase and wind-speed reduction (Wang et al., 2017). The urban heat island (UHI) effect causes a detectable decrease of daytime $\mathrm{O}_{3}$ concentration $(1.3 \mathrm{ppb})$ and an increase of $\mathrm{O}_{3}(5.2 \mathrm{ppb})$ around the nocturnal rushhours ( $\mathrm{Li}$ et al., 2016). $\mathrm{NO}_{\mathrm{x}}$ availability is the most significant parameter responsible for nonlinear behavior in ozone photochemistry in the central and southwestern PRD (Wang et al., 2011). The interactions between urbanization and thermal circulations play an important role in regional $\mathrm{O}_{3}$ formation ( $\mathrm{Li}$ et al., 2016). The maximum changes in daily mean air pollution concentration (as represented by $\mathrm{SO}_{2}$ concentration) caused by land use change and the anthropogenic emission distribution. The emission distribution exerts a more significant influence on air quality than land use change (Li et al., 2016). The regional urbanization and industrialization also have an effect on ozone pollution in PRD. With the system of highways and network of power plants were built in PRD, the ozone precursors, $\mathrm{NO}_{\mathrm{x}}$ and VOC emission from vehicles, industries, and power plants increased region wide, and in particular in the newly formed prefectural municipalities (Zhang et al., 2011). About $91.4 \%$ of $\mathrm{SO}_{2}$ emissions were from power plant and industrial sources, and $87.2 \%$ of $\mathrm{NO}_{\mathrm{x}}$ emissions were from the power plant and mobile sources (Zheng et al., 2009). Figure 3 presented the concentration of $\mathrm{PM}_{2.5}$ and $\mathrm{PM}_{10}$ in PRD. The industrial, mobile and power plant sources are major contributors to $\mathrm{PM}_{10}$ and $\mathrm{PM}_{2.5}$ emissions, accounting for $97.7 \%$ of the total $\mathrm{PM}_{10}$ and $97.2 \%$ of $\mathrm{PM}_{2.5}$ emissions (Zheng et al., 2009). Severe regional pollution of primary and secondary pollutants was mostly caused by emission sources and physical-chemical processes within the PRD area. Transport of pollutants from the outside of PRD was insignificant (Zhang et al., 2008). Vehicular and industrial emissions were the main sources of Non-methane hydrocarbons (Tang et al., 2007).

\subsection{VOC, Pops, and DDT}

Air is a perfect medium for monitoring of POPs in terms of transport and redistribution. DDTs are released into the atmosphere by agricultural spray drift, post-application volatilization, and wind erosion. Generally, almost all mean concentrations of DDTs in urban, suburban, and rural areas of the PRD were significantly higher than those observed at a rural site in Hong Kong. Levels of atmospheric HCHs in rural sites around the PRD were much lower than those in urban sites of Guangzhou, Hong Kong, and Zhaoqing (Fu et al., 2003). Mobile, biogenic and VOC product-related sources are responsible for 90.5\% of the total VOC emissions (Zheng et al., 2009). Meanwhile, mean concentrations of DDTs in urban and suburban areas were much higher than those obtained in rural areas of Dongguan and Shunde (Yue et al., 2011). The urban area of Guangzhou contained higher levels of DDTs than its suburban area whereas the urban area of Hong Kong showed significantly lower concentrations than its suburban area (Li et al., 2007, Yang et al., 2008). Temporally, similar mean concentrations of gaseous DDTs in the urban areas of Guangzhou and Hong Kong were found in $2006 \sim 2007$ (Ling, 2011) as compared to the results obtained in $2003 \sim 2004$ by Li et al. (2007), showing that use of DDTs in both regions may not have been controlled effectively. Sources of POPs in the atmosphere include direct emissions, volatilization from soil and water, and soil erosion. Elevated concentrations of chlordane and DDTs were found in the ambient air of Guangzhou, China. The source of chlordane was very likely from the usage of technical chlordane in the early summer 2005 (Yang et al., 2008). A total 14 organochlorine pesticides (OCPs) species in the atmosphere were measured over the Pearl River Delta Region (PRDR) in one year duration from August 2006 to August 2007. Guangzhou had the highest concentration of DDTs and the mean concentrations of OCPs at these sampling sites were higher than those obtained in other rural/urban regions in the world (Ling, 2011). The concentrations of most OCPs in summer were higher than those in winter (Ling, 2011). The results indicated that the high concentrations of OCP were mainly related to air mass through the potential source regions through long-range transport and local usage should not be overlooked (Ling, 2011). Hazards associated with these pollutants are their persistence in the environment, their bioaccumulation potential in the tissues of animals and humans through the food chain, and their toxic properties for humans and wildlife. POPs may also be transported for long distances by air, rivers and ocean currents, and contaminate regions remote from their source, and then lead to cross-boundary problems that need international efforts for the control of them.

\subsection{Metal}

Wong et al. (2003) found that atmospheric deposition of $\mathrm{Cr}, \mathrm{Cu}, \mathrm{Pb}$, and $\mathrm{Zn}$ in the PRD was significantly elevated compared with other regions, e.g., the Great Lakes region in North America and the North Sea in Europe. Elevated concentrations of metals, especially $\mathrm{Cd}, \mathrm{Pb}, \mathrm{V}$, and $\mathrm{Zn}$, were observed in the urban and suburban areas of Guangzhou, showing significant atmospheric trace element pollution (Lee et al., 2007). Researchers also found that the atmosphere in the PRD has suffered from mercury pollution (Chen et al., 2013, Huang et al., 2016). The ranges of daily average total gaseous mercury concentrations at the Dinghu and Guangzhou were $1.87 \sim 29.9$ $\mathrm{ng} / \mathrm{m}^{3}$ and $2.66 \sim 11.1 \mathrm{ng} / \mathrm{m}^{3}$ respectively (Chen et al., 2013). The atmospheric $\mathrm{Hg}$ deposition flux ranged from 43.70 to $321.19 \mathrm{~g} / \mathrm{m}^{2} / \mathrm{yr}$ in PRD (Huang et al., 2016).

Atmospheric emissions represent a major pathway of anthropogenic inputs of heavy metals into the surface environment (Wong et al., 2003). The seasonal variations in the metal concentrations of the aerosols in Guangzhou were less distinct, suggesting the dominance of local sources of pollution around 
the city (Lee et al., 2007). The Pb isotopic composition of the air deposits indicated that atmospheric inputs of $\mathrm{Pb}$ derived mainly from anthropogenic sources, e.g., vehicular exhaust and $\mathrm{Pb}$ ore in the PRD (Wong et al., 2003). Coal-fired emission is an important source of mercury for rural monitoring site and combined vehicle emissions and coal combustion were the dominant mercury sources for urban monitoring site (Chen et al., 2013). Source contributions to wet deposition were calculated by PMF, suggesting that dust, biomass burning, industries, vehicles, long-range transport and marine aerosol sources in Guangzhou, and Zn fertilizers, marine aerosol sources, agriculture, incense burning, biomass burning, vehicles and the ceramics industry in Dinghushan, were the potential sources of heavy metals (Ye et al., 2017). The ground effects driven by precipitation had a significantly affect relative to the mass transport effects (Huang et al. 2016).

Excessive inputs of heavy metals and other pollutants into the surface environment as a consequence of atmospheric deposition can impose a long-term burden on biogeochemical cycling in the ecosystem. Cd was classified as an extremely strong potential ecological risk based on solubility and the ecological risk index (Ye et al., 2017). Under the 30-year projecttion, the probability of risks caused by $\mathrm{Hg}$ deposition (combining $\mathrm{Hg}^{2+}$ and $\mathrm{MeHg}$ ) was the highest for 0- to 6-year children, followed by 6 - to 12 -year children and adults.

\subsection{Aerosol}

High levels of atmospheric aerosol pollutants, including $\mathrm{BC}$, sulfate, nitrate and organic carbon (OC), etc., have been emitted into and formed in the atmosphere because of human activities in PRD (Ansmann et al., 2005; Wendisch et al., 2008; Tan et al., 2016; Mai et al., 2018). The satellite (MODIS) data show that the aerosol optical depth is often higher than 0.6 in PRD, which is known as the Asian Brown Cloud region (Wu et al., 2005). According to studies that reported aerosol burden measured since 2000 in PRD. Almost all of the studies reported levels of annual mean $\mathrm{PM}_{10}$ clearly exceeding the WHO Air Quality Guidelines (AQG) of $20 \mu \mathrm{g} / \mathrm{m}^{3}$ and the Chinese Ambient Air Quality Standards ( $40 \mu \mathrm{g} / \mathrm{m}^{3}$ annual mean). $\mathrm{PM}_{2.5}$ were less frequently reported and exceeded AQG $\left(10 \mu \mathrm{g} / \mathrm{m}^{3}\right.$ annual and $25 \mu \mathrm{g} / \mathrm{m}^{3}$ daily) and the United States' National Ambient Air Quality Standards ( $15 \mu \mathrm{g} / \mathrm{m}^{3}$ annual and $35 \mu \mathrm{g} / \mathrm{m}^{3}$ daily) by far (Jahn et al., 2008). Aerosol hygroscopicity in the Pearl River Delta differs from other megacities in China and has a significant diurnal variation, and closely related to air mass origin (Tan et al., 2013).

In a particular event, the high aerosol levels is related to the hurricane (Wu et al., 2005). The sea-land breezes diurnal cycle played a significant role in the redistribution and transport of $\mathrm{PM}_{10}$ (Chen et al., 2007). The emission sources and the vertical diffusion were the major processes to influence the concentrations of particulate matter with an aerodynamic diameter less than $2.5 \mu \mathrm{m}$ (Chen et al., 2007). There are often high aerosol concentrations that have caused very low visibilities in PRD (Wu et al., 2005). An increase in atmospheric aerosols has caused deterioration of air quality and more frequent occurrence of hazy phenomena. In addition, changes in aerosol loading may also impact the regional and global climate by altering the radiation balance of the earth-atmospheric system.

\subsection{Micro-Plastics}

Fibers, foams, fragments, and films were found in atmospheric fallout in Dongguan city (Cai et al., 2017). According to the rate of identified samples, the concentrations of microplastics ranged from $31 \pm 8$ to $43 \pm 4$ particles $/ \mathrm{m}^{2} /$ day (Cai et al. 2017). The concentrations of nonfibrous microplastics and fibers ranged from 175 to 313 particles $/ \mathrm{m}^{2} /$ day in the atmospheric fallout. Dust emission from the land surface might be the main source of microplastics in the atmospheric fallout. Thus, dust emission and deposition between the atmosphere, land surface, and aquatic environment were associated with the transportation of microplastics (Cai et al., 2017). Microplastics have been proposed as one of ten emerging issues in UNEP Year Book 2014, and have been identified as an important factor leading to biodiversity loss (SC and RC, 2015) and pose a potential threat to human health and activities (Eerkesmedrano et al., 2015).

\subsection{Acid Rain}

PRD area is one of the most serious acid rain region in our country, where the acid rain with low $\mathrm{pH}$ value occurs frequently. The PRD region has suffered heavily from acid rain in the last 10 years due to the anthropogenic emission of sulfur dioxide and nitrogen dioxide ( $\mathrm{Lu}$ et al., 2015). The acid rain belonged to the sulfate-nitrate mixed type and Guangzhou was the city most affected by acid rain in this region (Lu et al., 2015). The source apportionment result suggests that point source (power plant and industrial process) and super regional source are the ones that contribute the pollutants most in the rainwater over PRD Region (Lu et al., 2015). Acid rain plays a significant role in acidifying the groundwater. Acid rain threatens food security by increasing the biotic availability of heavy metals in soil and in the aquatic environment. Excessive amounts of heavy metals accumulate in crops, causing a threat to human health (Mcdonald, 1985). Moreover, the increased nitrate concentration in drinking water caused by acid rain also increases the risk of methemoglobinemia infection and stomach cancer among infants and older people (Gulis et al., 2002). By far, the acidified groundwater, mainly caused by acid rain, has become the major environmental problem for groundwater (Jing, et al., 2010). High intensity acid rain also has an influence on heavy metal element release from moisture soils (Zhan et al., 2010) and the change of soil organic matter content of moisture soil in PRD (Li et al., 2011).

\section{Soil Environmental Pollution}

\subsection{Heavy Metals}

There is a growing public concern over the potential accumulation of heavy metals in soils in China owing to rapid urban and industrial development and increasing reliance on agrochemicals in the last several decades. Studies have shown that the crop, paddy and natural soils in many sampling sites of PRD 


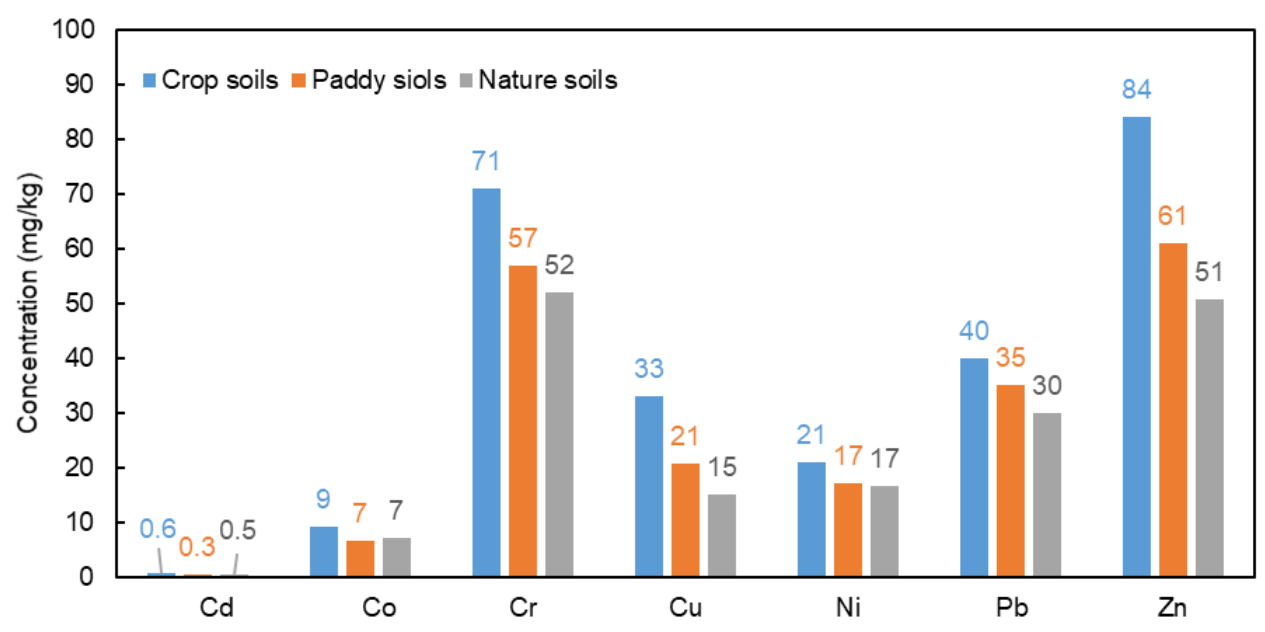

Figure 4. Heavy metal concentrations (mean value) of crop soils, paddy soils, and natural soils in the PRD. (Data from Wong et al. 2002).

were enriched with $\mathrm{Cd}$ and $\mathrm{Pb}$ (Wong et al., 2002). The soil was contaminated by $\mathrm{Pb}$ and $\mathrm{Ni}$ in great universality, and the other heavy metals $\mathrm{Cd}, \mathrm{Cr}, \mathrm{Cu}$, and $\mathrm{Zn}$ exceeded the back-ground value in a typical area of PRD under intensive economic development (Ma et al., 2004). The degree of pollution decreased in the order $\mathrm{Cd}>\mathrm{Cu}>\mathrm{Ni}>$ centrations of $\mathrm{As}$ and $\mathrm{Cd}$ in a large area of the PRD exceeded the National Second-class Standard (Zhang et al., 2015) $\mathrm{Zn}>\mathrm{As}>\mathrm{Cr}>\mathrm{Hg}>\mathrm{Pb}$ in surface soils from the PRD (Bai and Liu, 2014). The degree of heavy metal pollution by land use decreased in the order waste treatment plants $(\mathrm{WP})>$ urban land (UL) $>$ manufacturing industries (MI) $>$ agricultural land $(\mathrm{AL})>$ woodland $(\mathrm{WL})>$ water sources (WS) (Bai and Liu, 2014). Figure 4 presented the heavy metal concentrations of crop soils, paddy soils, and natural soils. Heavy metal enrichment was most significant in the crop soils, which might be attributed to the use of agrochemicals (Wong et al., 2002). It was evident that some of the soils were enriched with anthropogenic $\mathrm{Pb}$, such as industrial and automobile $\mathrm{Pb}$ (Wong et al., 2002). Pollution with some of the metals, including $\mathrm{Cd}, \mathrm{Cu}, \mathrm{Ni}$, and $\mathrm{Zn}$, was attributed to the recent rapid development of the electronics and electroplating industries (Bai and Liu, 2014).The control of $\mathrm{Cd}, \mathrm{Hg}$, and $\mathrm{Pb}$ should be prioritized in the PRD, and emissions in waste water, residue, and gas discharges from the electronics and electroplating industry should be decreased urgently (Bai and $\mathrm{Liu}, 2014$ ). $\mathrm{Cd}, \mathrm{Hg}$, and $\mathrm{Pb}$ pose high potential ecological risks in all of the zones studied and the potential ecological risk index followed the order $\mathrm{Cd}>\mathrm{Hg}$ $>\mathrm{Pb}>$ As (Zhang et al., 2015). Excessive accumulation of heavy metals in agricultural soils may not only result in environmental contamination, but elevated heavy metal uptake by crops may also affect food quality and safety (Wong et al., 2002). The migration of $\mathrm{Cd}$ also resulted in considerable ecological risk to the Beijiang and Xijiang River watershed (Zhang et al., 2015).

Owing to the Industrial Revolution in the late 1970s, heavy metal pollution has been regarded as a serious threat to mangrove ecosystems in the region of the Pearl River Estuary, po- tentially affecting human health. All heavy metals, except Mn, decreased with depth, indicating that heavy metal pollution has been deteriorating since 1979 . Worse still, the dominant plants in Nansha mangrove had limited capability to remove the heavy metals from sediment (Wu et al., 2014). Iron, $\mathrm{Cr}$, and $\mathrm{Cu}$ were identified as metal pollutants of primary concern and had higher contributions to the total toxic units compared to other metals (Bai et al., 2011). Almost all metals exceeded their lowest effect levels and $\mathrm{Fe}$ and $\mathrm{Cr}$ even exceeded the severe effect levels (Bai et al., 2011). The surface sediment was severely contaminated with heavy metals, probably due to the discharge of industrial sewage into the Pearl River Estuary (Wu et al., 2014). Fe and Mn are controlled by parent rocks and other metals mainly originate from the anthropogenic sources (Bai et al., 2011). The ecological risk of heavy metals was very high in the region of the Pearl River Estuary, largely due to $\mathrm{Cd}$ contamination (Wu et al., 2014).

\subsection{Pesticide}

Spatially, levels of DDTs in soils of the inland PRD were one to two orders of magnitude higher than those in soils from Hong Kong, consistent with larger application amount of DDTs in the inland PRD than in Hong Kong. Farming soils, especially those for growing vegetables, contained significantly higher levels of DDTs $(10.2 \sim 89.7 \mathrm{ng} / \mathrm{g})$ than natural soils $(0.37 \sim 8.0$ $\mathrm{ng} / \mathrm{g}$ ) ( $\mathrm{Li}$ et al., 2006). Rice paddy fields were shown to be heavily DDT-contaminated soils (Fu et al., 2003). On the other hand, levels of DDTs (21.4 to $89.7 \mathrm{ng} / \mathrm{g}$ ) in farming soils of the PRD region were much higher than the average level (10.2 ng/g) in Guangdong Province (Fu et al., 2003; Yang et al., 2007).

A recent study investigated the levels of DDTs in different land use types of Shenzhen as presented in Figure 5. The mean concentrations followed the order of traffic $(149 \mathrm{ng} / \mathrm{g})>$ industrial $(71 \mathrm{ng} / \mathrm{g})>\operatorname{residential}(41 \mathrm{ng} / \mathrm{g})>$ farming $(25 \mathrm{ng} / \mathrm{g})>$ green belt $(8.6 \mathrm{ng} / \mathrm{g})>$ commerce $=$ orchard $(0.4 \mathrm{ng} / \mathrm{g})>$ forest $(\sim 0$ $\mathrm{ng} / \mathrm{g}$ ) (Qin et al., 2011). Higher concentrations of DDTs in traf- 
fic, industrial, and residential lands than those in cultivation land were consistent with the result that levels of DDTs in air and precipitation were higher in urban areas than in rural areas (Yue et al., 2011). Higher concentrations of legacy organ-ochlorine pesticides (OCPs) and current-use insecticides (CUPs) occurred in the central PRD with more urbanization level than that in the PRD's surrounding areas (Wei et al., 2015). Researchers attributed the spatial distribution pattern of DDTs to the large amounts of DDTs applied in former farming lands located around urban areas that have been converted into traffic, industrial and residential use as a result of rapid urbanization in the PRD (Yue et al., 2011). Relatively higher concentrations of OCPs and CUPs were found in the residency land than in other land-use types which may be attributed to landuse change under rapid urbanization (Wei et al., 2015). An enhanced land soil runoff in the process of large-scale land transform, as well as a higher river water flow in early 1990s, had mobilized these pesticides from soil to the sedimentary system in the region (Zhang et al., 2002). Many organochlorine POPs have a high affinity for soil and are retained in this environment medium POPs may be taken up by crops and by grazing animals and hence reach the human food chain. Risk assessment against existing criteria indicated that the levels of DDTs in water and some fish species may pose adverse effects to humans or wildlife, and those in sediment/soil may also cause negative impacts to the eco-environment of the PRD (Guo et al., 2009).

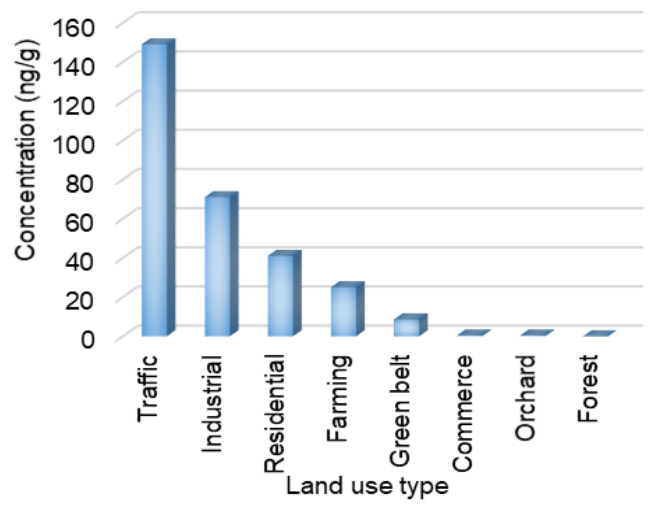

Figure 5. The levels of DDTs in different land use types. (Data from Qin et al. 2011).

\subsection{Other Organics}

Higher soil PAH concentrations occurred in the central PRD characterized by dense population and high urbanization level (Wei et al., 2014). Source diagnostics implicated the combustions of coal and refined petroleum as the major input sources of anthropogenic PAHs (Wei et al., 2014). The central PRD may have become a secondary source of PAHs to the surrounding areas (Wei et al., 2014). The source of PAHs (polycyclic aromatic hydrocarbons) is petroleum, and combustion of fossil fuel, biomass, and coal. PAHs in Pearl River Estuary (PRE) and northern South China Sea (SCS) are probably mainly inputted from the soils in PRD via soil erosion and river transport (Ma et al., 2008). Insecticide spatial distributions may be driven by economic prosperity (Wei et al., 2015). Ecological risk assessment showed that $3.5 \%$ of soil within the central PRD was heavily contaminated by polycyclic aromatic hydrocarbons (PAHs) and 5.2 million residents may be subjected to high health risk (Wei et al., 2014). As predicted local residents in the PRD and surrounding areas will expose to the high health risk for pyrethroids by 2109 (Wei et al., 2015).

\section{Conclusion}

Rapid economic growth in the Pearl River Delta (PRD) region, south China, has resulted in severe pollution of the natural eco-environment since the reform and opening up. Of various sources for eco-environmental deterioration, the negative impact of environmental pollutants is a global concern. Rapid economic growth in the PRD has resulted in severe pollution of the natural eco-environment since the reform and opening up. Now, PRD is facing great challenges because of heavy metal contamination, organics, nutrients, and so on. This review examines common environmental pollutions (e.g., heavy metals, organics) mainly in water, air, and soil. The general information of these pollutions on current levels, possible causes, and potential effects in PRD are reviewed. The main findings are as follows.

Firstly, the heavy metals had an increasing trend in PRD in recent decades, especially for $\mathrm{Cr}$. The sediments in coastal wetlands were significantly contaminated by $\mathrm{Cd}, \mathrm{Zn}$ and $\mathrm{Ni}$. Heavy metal enrichment was most significant in PRD, which might be attributed to the use of agrochemicals, and the recent rapid development of the electronics and electroplating industries. Nonpoint source pollution (with nitrate and related compounds) due to agriculture is a major issue affecting water. The discharge of industrial effluents and domestic sewage seems to cause nutrient and heavy metal pollution in environmental media. Secondly, atmospheric emissions of gaseous and particulate pollutants have caused profound environmental and health implications. The interactions between urbanization and thermal circulations play an important role in regional atmospheric pollution formation. The emission distribution exerts a more significant influence on air quality than land use change. Thirdly, the increase of urban population and the improvement of people's living quality bring about serious situation of garbage siege in many cities such as Guangzhou. The main waste generator in PRD is construction waste. Growing public concern over the potential accumulation of heavy metals in soils owing to rapid urban and industrial development

In general, the water environment pollution in the Pearl River Delta region is the most serious and the most concerned. The air pollution has the worst impact, resulting in extreme events such as smog and acid rain. Soil pollution needs more attention due to the lack of monitoring data. More objectiveoriented monitoring and research programs may be carried out to fill the existing data gaps.

Acknowledgments. This research is supported by the National Key 
Research and Development Plan (2016YFA0601502), (2016YFC0502800), the Natural Sciences Foundation (51520105013, 51679087), the 111 Program (B14008), and the Natural Science and Engineering Research Council of Canada.

\section{References}

Ansmann, A., Engelmann, R., Althausen, D., Wandinger, U., Hu, M., Zhang, Y., and He, Q. (2005). High aerosol load over the Pearl River Delta, China, observed with Raman lidar and Sun photometer. Geophysical Research Letters, 32(13), 313-320. https://doi.org/10. 1029/2005GL023094

Bai, J., Xiao, R., Cui, B., Zhang, K., Wang, Q., Liu, X., Gao, H. and L. Huang (2011). Assessment of heavy metal pollution in wetland soils from the young and old reclaimed regions in the Pearl River Estuary, South China. Environmental Pollution, 159(3), 817-824. https://doi. org/10.1016/j.envpol.2010.11.004

Bai, J.M. and Liu, X.P. (2014). Heavy metal pollution in surface soils of Pearl River Delta, China. Environmental Monitoring and Assessment, 186(12), 8051-8061. https://doi.org/10.1007/s10661-014-40 50-9

Cai, J., Cao, Y., Tan, H., Wang Y., and Luo, J. (2011). Fractionation and ecological risk of metals in urban river sediments in Zhongshan City, Pearl River Delta. Journal of Environmental Monitoring, 13(9), 2450-2456. https://doi.org/10.1039/c1em10062a

Cai, L., Wang, J., Peng, J., Tan, Z., Zhan, Z., Tan, X., and Chen, Q. (2017). Characteristic of microplastics in the atmospheric fallout from Dongguan city, China: preliminary research and first evidence. Environmental Science and Pollution Research International, 24(32), 24928-24935. https://doi.org/10.1007/s11356-017-0116-x

Chen, L., Liu, M., Xu, Z., Fan, R., Tao, J., Chen, D., Zhang, D., Xie, D., and Sun, J. (2013). Variation trends and influencing factors of total gaseous mercury in the Pearl River Delta-A highly industrialised region in South China influenced by seasonal monsoons. Atmospheric Environment, 77, 757-766. https://doi.org/10.1016/j. atmosenv.2013.05.053

Chen, R., Yin, P., Zhao, L., Yu, Q., Hong, A., and Duan, S. (2014). Spatial-temporal distribution and potential ecological risk assessment of nonylphenol and octylphenol in riverine outlets of Pearl River Delta, China. Journal of Environmental Sciences (China), 26(11), 2340-2347. https://doi.org/10.1016/j.jes.2014.09. 019

Chen, X.L., Feng, Y.R., Li, J.N., Lin. W.S., Fan. S.J., Wang. A.Y., Fong. S.K., and Hui, L. (2007). Numerical simulations on the effect of sealand breezes on atmospheric haze over the Pearl River Delta Region. Environmental Modeling \& Assessment, 14(3), 351-363. https://doi. org/10.1007/s10666-007-9131-5

Cheng, Z., Chen, K.C., Li, K.B., Nie, X.P., Wu, S.C., Wong, C.K., and Wong, M.H. (2013a). Arsenic contamination in the freshwater fish ponds of Pearl River Delta: bioaccumulation and health risk assessment. Environmental Science and Pollution Research International, 20(7), 4484-4495. https://doi.org/10.1007/s11356- 012-1382-2

Cheng, Z., Liang, P., Shao, D.D., Wu, S.C., Nie, X.P., Chen, K.C., Li, K.B., and Wong, M.H. (2011). Mercury biomagnification in the aquaculture pond ecosystem in the Pearl River Delta. Archives of Environmental Contamination and Toxicology, 61(3), 491-499. https://doi.org/10.1007/s00244-010-9641-Z

Cheng, Z., Man, Y.B., Nie, X.P., and Wong, M.H. (2013b). Trophic relationships and health risk assessments of trace metals in the aquaculture pond ecosystem of Pearl River Delta, China. Chemosphere, 90(7), 2142-2148. https://doi.org/10.1016/j.chemo sphere.2012.11.017

Clark, M.P., Nijssen, B., Lundquist, J.D., Kavetski, D., Rupp, D.E., Woods, R.A., Freer, J.E., Gutmann, E.D., Wood, A.W., and Brekke, L.D. (2015). A unified approach for process-based hydrologic modeling: 1. Modeling concept. Water Resources Research, 51(4),
2498-2514. https://doi.org/10.1002/2015WR017198

Eerkesmedrano, D., Thompson, R.C., and Aldridge, D.C. (2015). Microplastics in freshwater systems: A review of the emerging threats, identification of knowledge gaps and prioritisation of research needs. Water Research, 75(3), 63-82. https://doi.org/10. 1016/j.watres.2015.02.012

Fan, X., Cui, B., Zhao, H., Zhang, Z., and Zhang, H. (2010). Assessment of river water quality in Pearl River Delta using multivariate statistical techniques. Procedia Environmental Sciences, 2, 12201234. https://doi.org/10.1016/j.proenv.2010.10.133

Fang, Z., Cheung, R., and Wong, M. (2001). Concentrations and distribution of organochlorinated pesticides and PCBs in greenlipped mussels, Perna viridis collected from the Pearl River estuarine zone. Acta scientiae circumstantiae, 21(1), 113-116, Beijing.

Fu, J., Mai, B., Sheng, G., Zhang, G., Wang, X., Peng, P.A., Xiao, X., Ran, R., Cheng, F., Peng, X., Wang, Z., and U.W. Tang (2003). Persistent organic pollutants in environment of the Pearl River Delta, China: an overview. Chemosphere, 52(9), 1411-1422. https://doi. org/10.1016/S0045-6535(03)00477-6

Fung, C.N., Zheng, G.J., Connell, D.W., Zhang, X., Wong, H.L., Giesy, J.P., Fang, Z., and Lam, P.K. (2005). Risks posed by trace organic contaminants in coastal sediments in the Pearl River Delta, China. Marine Pollution Bulletin, 50(10), 1036-1049. https://doi.org/10.10 16/j.marpolbul.2005.02.040

Gall, S.C. and Thompson, R.C. (2015). The impact of debris on marine life. Marine Pollution Bulletin, 92(170), 1-2. https://doi.org/10.10 16/j.marpolbul.2014.12.041

Gan, J.L., Jia, X.P., Jia, T., Lin, Q., and Cai, W.G. (2009). Distribution and change of DDT and $\mathrm{HCH}$ levels in oysters (Crassostrea rivularis) from coast of Guangdong, China between 2003 and 2007. Journal of Environmental Science and Health, Part B: Pesticides, Food Contaminants and Agricultural Wastes, 44(8), 817-822. https://doi. org/10.1080/03601230903238657

Gong, J., Ran, Y., Chen, D.Y., and Yang, Y. (2011). Occurrence of endocrine-disrupting chemicals in riverine sediments from the Pearl River Delta, China. Marine Pollution Bulletin, 63(5-12), 556-563. https://doi.org/10.1016/j.marpolbul.2011.01.026

Guan, Y.F., Wang, J.Z., Ni, H.G., and Zeng, E.Y. (2009). Organochlorine pesticides and polychlorinated biphenyls in riverine runoff of the Pearl River Delta, China: assessment of mass loading, input source and environmental fate. Environmental Pollution, 157(2), 618-624. https://doi.org/10.1016/j.envpol.2008.08.011

Gulis, G., Czompolyova, M., and Cerhan, J.R. (2002). An ecologic study of nitrate in municipal drinking water and cancer incidence in Trnava District, Slovakia. Environmental Research, 88(3), 182-187. https://doi.org/10.1006/enrs.2002.4331

Guo, L., Qiu, Y., Zhang, G., Zheng, G.J., Lam, P.K., and Li, X. (2008). Levels and bioaccumulation of organochlorine pesticides (OCPs) and polybrominated diphenyl ethers (PBDEs) in fishes from the Pearl River estuary and Daya Bay, South China. Environmental Pollution, 152(3), 604-611. https://doi.org/10.1016/j.envpol.2007. 06.067

Guo, Y., Yu, H.Y., and Zeng, E.Y. (2009). Occurrence, source diagnosis, and biological effect assessment of DDT and its metabolites in various environmental compartments of the Pearl River Delta, South China: a review. Environmental Pollution, 157(6), 1753-1763. https://doi.org/10.1016/j.envpol.2008.12.026

Han, D. and Currell, M.J. (2017). Persistent organic pollutants in China's surface water systems. Science of the Total Environment, 580, 602-625. https://doi.org/10.1016/j.scitotenv.2016.12.007

Han, J.C., Huang, Y., Li, Z., Zhao, C., Cheng, G., and Huang, P. (2016). Groundwater level prediction using a SOM-aided stepwise cluster inference model. Journal of Environmental Management, 182, 308321. https://doi.org/10.1016/j.jenvman.2016.07.069

He, X., Deng, M., Wang, Q., Yang, Y., Yang, Y., and Nie, X. (2016). Residues and health risk assessment of quinolones and sulfo- 
namides in cultured fish from Pearl River Delta, China. Aquaculture, 458, 38-46. https://doi.org/10.1016/j.aquaculture.2016.02.006

He, X., Wang, Z., Nie, X., Yang, Y., Pan, D., Leung, A.O., Cheng, Z., Yang, Y., Li, K., and Chen, K. (2012). Residues of fluoroquinolones in marine aquaculture environment of the Pearl River Delta, South China. Environmental Geochemistry and Health, 34(3), 323-335. https://doi.org/10.1007/s10653-011-9420-4

Hills, P., Zhang, L., and Liu, J. (1998). Transboundary pollution between Guangdong Province and Hong Kong: threats to water quality in the Pearl River Estuary and their implications for environmental policy and planning. Journal of Environmental Planning and Management, 41(3), 375-396. https://doi.org/10.108 0/09640569811641

Huang, D.Y., Peng, P.A., Xu, Y.G., Sun, C.X., Deng, H.M., and Deng, Y.Y. (2010). Distribution, regional sources and deposition fluxes of organochlorine pesticides in precipitation in Guangzhou, South China. Atmospheric Research, 97(1), 115-123. https://doi.org/10. 1016/j.atmosres.2010.03.013

Huang, M., Deng, S., Dong, H., Dai, W., Pang, J., and Wang, X. (2016). Impacts of atmospheric mercury deposition on human multimedia exposure: projection from observation in the Pearl River Delta Region, South China. Environmental Science \& Technology, 50(19), 10625-10634. https://doi.org/10.1021/acs.est.6b00514

Huang, X.P., Huang, L.M., and Yue, W.Z. (2003). The characteristics of nutrients and eutrophication in the Pearl River estuary, South China. Marine Pollution Bulletin, 47(1-6), 30-36. https://doi.org /10.1016/S0025-326X(02)00474-5

Huang, Y., Zhu, W., Le, M., and Lu, X. (2012). Temporal and spatial variations of heavy metals in urban riverine sediment: An example of Shenzhen River, Pearl River Delta, China. Quaternary International, 282, 145-151. https://doi.org/10.1016/j.quaint.2011.05.026

Jahn, H., Eißner, R., Wendisch, M., and Krämer, A. (2008). Aerosol pollution over the Pearl River Delta, P.R. China. Amount and possible health risks - a systematic literature review.

Jahn, H.J., Schneider, A., Breitner, S., Eißner, R., Wendisch, M., and Krämer, A. (2011). Particulate matter pollution in the megacities of the Pearl River Delta, China-A systematic literature review and health risk assessment. International Journal of Hygiene and Environmental Health, 214(4), 281-295. https://doi.org/10.1016/j. ijheh.2011.05.008

Jing, J.H., Sun, J.C., Han, S.P., Huang, G.X., Chen, X., Zhang, Y.X., and Liu, J.T. (2010). Distributions of Acid Rain and Acidified Groundwater in Pearl River Deltas. Shanghai Geology, 2, 8-11.

Kang, Y., Sheng, G., Fu, J., Mai, B., Zhang, G., Lin, Z., and Min, Y. (2000). Polychlorinated biphenyls in surface sediments from the Pearl River Delta and Macau. Marine Pollution Bulletin, 9(40), 794797. https://doi.org/10.1016/S0025-326X(00)00089-8

Lee, C.S.L., Li, X.D., Zhang, G., Li, J., Ding, A.J., and Wang, T. (2007). Heavy metals and $\mathrm{Pb}$ isotopic composition of aerosols in urban and suburban areas of Hong Kong and Guangzhou, South ChinaEvidence of the long-range transport of air contaminants. Atmospheric Environment, 41(2), 432-447. https://doi.org/10.101 6/j.atmosenv.2006.07.035

Leung, H.M., Leung, A.O., Wang, H.S., Ma, K.K., Liang, Y., Ho, K.C., Cheung, K.C., Tohidi, F., and Yung, K.K. (2014). Assessment of heavy metals/metalloid ( $\mathrm{As}, \mathrm{Pb}, \mathrm{Cd}, \mathrm{Ni}, \mathrm{Zn}, \mathrm{Cr}, \mathrm{Cu}, \mathrm{Mn}$ ) concentrations in edible fish species tissue in the Pearl River Delta (PRD), China. Marine Pollution Bulletin, 78(1-2), 235-245. https:// doi.org/10.1016/j.marpolbul.2013.10.028

Li, F., Zeng, X.Y., Wu, C.H., Duan, Z.P., Wen, Y.M., Huang, G.R., Long, X.L., Li, M.J., and Xu, J.Y. (2013). Ecological risks assessment and pollution source identification of trace elements in contaminated sediments from the Pearl River Delta, China. Biological Trace Element Research, 155(2), 301-313. https://doi.org/10.1007/ s12011-013-9789-2

Li, J., Zhang, G., Guo, L., Xu, W., Li, X., Lee, C.S.L., Ding, A., and
Wang, T. (2007). Organochlorine pesticides in the atmosphere of Guangzhou and Hong Kong: Regional sources and long-range atmospheric transport. Atmospheric Environment, 41(18), 38893903. https://doi.org/10.1016/j.atmosenv.2006.12.052

Li, J., Zhang, G., Qi, S., Li, X., and Peng, X. (2006). Concentrations, enantiomeric compositions, and sources of HCH, DDT and chlordane in soils from the Pearl River Delta, South China. Science of the Total Environment, 372(1), 215-224. https://doi.org/10.1016/j.scito tenv.2006.09.023

Li, M., Song, Y., Mao, Z., Liu, M., and Huang, X. (2016a). Impacts of thermal circulations induced by urbanization on ozone formation in the Pearl River Delta region, China. Atmospheric Environment, 127, 382-392. https://doi.org/10.1016/j.atmosenv.2015.10.075

Li, Q., Wu, Z., Chu, B., Zhang, N., Cai, S., and Fang, J. (2007). Heavy metals in coastal wetland sediments of the Pearl River Estuary, China. Environmental Pollution, 149(2), 158-164. https://doi.org/10. 1016/j.envpol.2007.01.006

Li, X., Yin, P., and Zhao, L. (2016). Phthalate esters in water and surface sediments of the Pearl River Estuary: distribution, ecologi$\mathrm{cal}$, and human health risks. Environmental Science and Pollution Research International, 23(19), 19341-19349. https://doi.org/10.10 07/s11356-016-7143-x

Li, Z., Yang, X., Zeng, Y., and Chen, F. (2011). Study on the Change of Soil Organic Matter Content of Moisture Soil in Pearl River Delta by High Intensity Simulated Acid Rain Leaching Experiment. Guangdong Chemical Industry.

Li, Z.Q., Yang, X.Y., Mo, S.W., and Chen, F.Q. (2010). Influence of high intensity simulated acid rain on heavy metal element release from moisture soils in Pearl River Delta. Rock \& Mineral Analysis 29(2), 136-138.

Ling, Z. (2011). Characterizing the Gas-phase Organochlorine Pesticides in the Atmosphere over the Pearl River Delta Region. Aerosol and Air Quality Research. https://doi.org/10.4209/aaqr.2010.11. 0097

Liu, Z., Wang, Y., Li, Z., and Peng, J. (2012). Impervious surface impact on water quality in the process of rapid urbanization in Shenzhen, China. Environmental Earth Sciences, 68(8), 2365- 2373. https://doi.org/10.1007/s12665-012-1918-2

Lu, X., Fung, J.C.H., and Wu, D. (2015). Modeling wet deposition of acid substances over the PRD region in China. Atmospheric Environment, 122, 819-828. https://doi.org/10.1016/j.atmosenv.20 15.09.035

Lu, Y., Tang, C., Chen, J., and Sakura, Y., (2010). Impact of septic tank systems on local groundwater quality and water supply in the Pearl River Delta, China: case study. Hydrological Processes, 22(3), 443450. https://doi.org/10.1002/hyp.6617

Ma, J., Pan, G.X., Wan, H.F., Xia, Y.S., and Luo, W. (2004). Investigation on heavy metal pollution in a typical area of the Pearl River Delta. Chinese Journal of Soil Science, 35(5), 636-638.

Ma, X., Ran, Y., Gong, J., and Zou, M. (2008). Concentrations and inventories of polycyclic aromatic hydrocarbons and organochlorine pesticides in watershed soils in the Pearl River Delta, China. Environmental Monitoring and Assessment, 145(1-3), 453-464. https://doi.org/10.1007/s10661-007-0054-z

Mai, B., Deng, X., Li, Z., Liu, J., Xia, X.A., Che, H., Liu, X., Li, F., Zou, Y., and Cribb, M. (2018). Aerosol optical properties and radiative impacts in the Pearl River Delta region of China during the dry season. Advances in Atmospheric Sciences. 35(2), 195-208. https://doi.org/10.1007/s00376-017-7092-4

Mai, B.X., Fu. J.M., Gan, Z., Zheng, L., Min, Y.S., Sheng, G.Y., and Wang, X.M. (2001). Polycyclic aromatic hydrocarbons in sediments from the Pearl River and estuary, China: spatial and temporal distribution and sources. Applied Geochemistry, 16(11-12), 14291445. https://doi.org/10.1016/S0883-2927(01)00050-6

Mcdonald, M.E. (1985). Acid deposition and drinking water. Environmental Science \& Technology, 19(9), 772-776. https://doi. 
org/10.1021/es00139a002

Ouyang, T., Zhu, Z., and Kuang, Y. (2006). Assessing impact of urbanization on river water quality in the Pearl River Delta Economic Zone, China. Environmental Monitoring and Assessment 120(1-3), 313-325. https://doi.org/10.1007/s10661-005-9064-x

Peng, X., Yu, Y., Tang, C., Tan, J., Huang, Q., and Wang, Z. (2008). Occurrence of steroid estrogens, endocrine-disrupting phenols, and acid pharmaceutical residues in urban riverine water of the Pearl River Delta, South China. Science of the Total Environment, 397(13), 158-166. https://doi.org/10.1016/j.scitotenv.2008.02.059

Qin, P.H., Ni, H.G., Liu, Y.S., Shi, Y.H., and Zeng, H. (2011). Occurrence, distribution, and source of polybrominated diphenyl ethers in soil and leaves from Shenzhen Special Economic Zone China. Environmental Monitoring and Assessment, 174(1-4), 259270. https://doi.org/10.1007/s10661-010-1455-y

Ren, J., Liu, H., Ding, S., Wang, M., and Bian, Z. (2017). Landscape pattern change and its driving mechanism in Yihe River basin. China. Journal of Applied Ecology, 28, 2611-2620.

Tan, H., Liu, L., Fan, S., Li, F., Yin, Y., Cai, M., and Chan, P.W. (2016). Aerosol optical properties and mixing state of black carbon in the Pearl River Delta, China. Atmospheric Environment, 131: 196-208. https://doi.org/10.1016/j.atmosenv.2016.02.003

Tan, H., Yin, Y., Gu, X., Li, F., Chan, P.W., Xu, H., Deng, X. and Wan, Q. (2013). An observational study of the hygroscopic properties of aerosols over the Pearl River Delta region. Atmospheric Environment, 77: 817-826. https://doi.org/10.1016/j.atmosenv.2013. 05.049

Tang, J.H., Chan, L.Y., Chan, C.Y., Li, Y.S., Chang, C.C., Liu, S.C. Wu, D., and Li, Y.D. (2007). Characteristics and diurnal variations of NMHCs at urban, suburban, and rural sites in the Pearl River Delta and a remote site in South China. Atmospheric Environment, 41(38), 8620-8632. https://doi.org/10.1016/j.atmosenv.2007.07.029

Wang, S.L., Xu, X.R., Sun, Y.X., Liu, J.L., and Li, H.B. (2013). Heavy metal pollution in coastal areas of South China: a review. Marine Pollution Bulletin, 76(1-2), 7-15. https://doi.org/10.1016/j.marpol bul.2013.08.025

Wang, X., Zhang, Y., Hu, Y., Zhou, W., Zeng, L., Hu, M., Cohan, D.S., and Russell, A.G. (2011). Decoupled direct sensitivity analysis of regional ozone pollution over the Pearl River Delta during the PRIDE-PRD2004 campaign. Atmospheric Environment 45(28), 4941-4949. https://doi.org/10.1016/j.atmosenv.2011.06.006

Wang, X.M., Chen, F., Wu. Z.H., Zhang. M.G., Tewari, M., Guenther, A., and Wiedinmyer, C. (2009). Impacts of weather conditions modified by urban expansion on surface ozone: Comparision between the Pearl River Delta and Yangtze River Delta Regions. Advances in Atmospheric Sciences, 26(5), 962-972. https://doi. org/10.1007/s00376-009-8001-2

Wang, X.M., Lin, W.S., Yang, L.M., Deng, R.R., and Lin, H. (2017). A numerical study of influences of urban land-use change on ozone distribution over the Pearl River Delta region, China. Tellus B Chemical and Physical Meteorology, 59(3), 633-641. https://doi. org/10.1111/j.1600-0889.2007.00271.x

Wei, Y.L., Bao, L.J., Wu, C.C., He, Z.C., and Zeng, E.Y. (2014). Association of soil polycyclic aromatic hydrocarbon levels and anthropogenic impacts in a rapidly urbanizing region: spatial distribution, soil-air exchange and ecological risk. Science of the Total Environment, 473-474: 676-684. https://doi.org/10.1016/j. scitotenv.2013.12.106

Wei, Y.L., Bao, L.J., Wu, C.C., He, Z.C., and Zeng, E.Y. (2015) Assessing the effects of urbanization on the environment with soil legacy and current-use insecticides: a case study in the Pearl River Delta, China. Sci Total Environ 514: 409-417. https://doi.org/10.10 16/j.scitotenv.2015.01.111

Wendisch, M., Ansraann, O.H., Heintzenberg, J., Engelmann, R., Althausen, D., Eichler, H., Miiller, D., Hu, M., Zhang, Y., and Mao, J. (2008). Radiative and dynamic effects of absorbing aerosol par- ticles over the Pearl River Delta, China. Atmospheric Environment, 42(25), 6405-6416. https://doi.org/10.1016/j.atmosenv.2008.02.033

Wong, C.S.C., Li, X.D., Zhang, G., Qi S.H., and Peng, X.Z. (2003). Atmospheric deposition of heavy metals in the Pearl River Delta, China. Atmospheric Environment, 37, 767-776. https://doi.org/10. 1016/S1352-2310(02)00929-9

Wong, S., Li, X., Zhang, G., Qi, S., and Min, Y. (2002). Heavy metals in agricultural soils of the Pearl River Delta, South China. Environmental pollution, 119(1), 33-44. https://doi.org/10.1016/ S0269-7491(01)00325-6

Wu, D., Tie, X., Li, C., Ying, Z., Kai-Hon Lau, A., Huang, J., Deng, X., and Bi, X. (2005). An extremely low visibility event over the Guangzhou region: A case study. Atmospheric Environment. 39(35), 6568-6577. https://doi.org/10.1016/j.atmosenv.2005.07. 061

Wu, Q., Tam, N.F., Leung, J.Y., Zhou, X., Fu, J., Yao, B., Huang, X., and Xia, L. (2014). Ecological risk and pollution history of heavy metals in Nansha mangrove, South China. Ecotoxicology and Environmental Safety, 104, 143-151. https://doi.org/10.1016/j.eco env.2014.02.017

Xiao, R., Bai, J., Huang, L., Zhang, H., Cui, B., and Liu, X., (2013). Distribution and pollution, toxicity and risk assessment of heavy metals in sediments from urban and rural rivers of the Pearl River delta in southern China. Ecotoxicology, 22(10), 1564-1575. https:// doi.org/10.1007/s10646-013-1142-1

Xu, W., Yan, W., Li, X., Zou, Y., Chen, X., Huang, W., Miao, L., Zhang, R., Zhang, G., and Zou, S. (2013). Antibiotics in riverine runoff of the Pearl River Delta and Pearl River Estuary, China: concentrations, mass loading and ecological risks. Environmental Pollution, 182, 402-407. https://doi.org/10.1016/j.envpol.2013.08.004

Yang, G.Y., Wan, K., Zhang, T.B., Guo, Z.X. Wan, H.F., Luo, W., and Gao, Y.X. (2007). Residues and distribution characteristics of organochlorine pesticides in agricultural soils from typical areas of Guangdong province. Journal of Agro-Environment Science, 26(5), 1619-1623.

Yang, Y., Li, D., and Mu, D. (2008). Levels, seasonal variations and sources of organochlorine pesticides in ambient air of Guangzhou, China. Atmospheric Environment, 42(4), 677-687. https://doi.org /10.1016/j.atmosenv.2007.09.061

Yang, Y., Sheng, G., Fu, J., and Min, Y. (1997). Organochlorinated compounds in waters of the Pearl River Delta Region. Environmental Monitoring \& Assessment, 44(1-3), 569-575. https:// doi.org/10.1023/A:1005743932046

Ye, L., Huang, M., Zhong, B., Wang, X., Tu, Q., Sun, H., Wang, C., Wu, L., and Chang, M. (2017). Wet and dry deposition fluxes of heavy metals in Pearl River Delta Region (China), Characteristics, ecological risk assessment, and source apportionment. Journal of Environmental Sciences. https://doi.org/10.1016/j.jes.2017.11.019

Guangdong Statistical Yearbook, (2017), China Statistics Press.

Yue, Q., Zhang, K., Zhang, B.Z., Li, S.M., and Zeng, E.Y. (2011). Occurrence, phase distribution and depositional intensity of dichlorodiphenyltrichloroethane (DDT) and its metabolites in air and precipitation of the Pearl River Delta, China. Chemosphere, 84(4), 446-451. https://doi.org/10.1016/j.chemosphere.2011.03.045

Zhang, B.Z., Ni, H.G., Guan, Y.F., and Zeng, E.Y. (2010). Occurrence, bioaccumulation and potential sources of polybrominated diphenyl ethers in typical freshwater cultured fish ponds of South China. Environmental Pollution, 158(5), 1876-1882. https://doi.org/10.10 16/j.envpol.2009.10.043

Zhang, G., Bai, J., Xiao, R., Zhao, Q., Jia, J., Cui, B., and Liu, X. (2017). Heavy metal fractions and ecological risk assessment in sediments from urban, rural and reclamation-affected rivers of the Pearl River Estuary, China. Chemosphere, 184, 278-288. https:// doi.org/10.1016/j.chemosphere.2017.05.155

Zhang, G., Parker, A., House, A., Mai, B., Li, X., Kang, Y., and Wang, Z. (2002). Sedimentary records of DDT and $\mathrm{HCH}$ in the Pearl River Delta, South China. Environmental Science \& Technology, 36, 
3671-3677. https://doi.org/10.1021/es0102888

Zhang, K., Wei, Y.L., and Zeng, E.Y. (2013). A review of environmental and human exposure to persistent organic pollutants in the Pearl River Delta, South China. Science of the Total Environment, 463, 1093-1110. https://doi.org/10.1016/j.scitotenv.2012.10.104

Zhang, L., Guo, S., and Wu, B., (2015). The source, spatial distribution and risk assessment of heavy metals in soil from the Pearl River Delta based on the national multi-purpose regional geochemical survey. PLoS One, 10(7), e0132040. https://doi.org/10.1371/journal. pone. 0132040

Zhang, R., Zhang, R., Zou, S., Yang, Y., Li, J., Wang, Y., Yu, K., and Zhang, G. (2017). Occurrence, distribution and ecological risks of fluoroquinolone antibiotics in the Dongjiang River and the Beijiang River, Pearl River Delta, South China. Bulletin of Environmental Contamination and Toxicology, 99(1), 46-53. https://doi.org/10. 1007/s00128-017-2107-5

Zhang, Y., Xiang, Y., Chan, L., Chan, C., Sang, X., Wang, R., and Fu, H. (2011). Procuring the regional urbanization and industrialization effect on ozone pollution in Pearl River Delta of Guangdong, China. Atmospheric environment, 45(28), 4898-4906. https://doi.org/10. 1016/j.atmosenv.2011.06.013

Zhang, Y.H., Hu, M., Zhong, L.J., Wiedensohler, A., Liu, S.C., Andreae, M.O., Wang, W., and Fan, S.J. (2008). Regional integrated experiments on air quality over Pearl River Delta 2004 (PRIDEPRD2004), overview. Atmospheric Environment, 42(25), 61576173. https://doi.org/10.1016/j.atmosenv.2008.03.025

Zheng, J., Zhang, L., Che, W., Zheng, Z., and Yin, S. (2009). A highly resolved temporal and spatial air pollutant emission inventory for the Pearl River Delta region, China and its uncertainty assessment. Atmospheric Environment, 43(32), 5112-5122. https://doi.org/10. 1016/j.atmosenv.2009.04.060

Zhou, J. L., Maskaoui, K., Qiu, Y.W., Hong, H.S., and Wang, Z.D. (2001). Polychlorinated biphenyl congeners and organochlorine insecticides in the water column and sediments of Daya Bay, China. Environmental Pollution, 113(3), 373-384. https://doi.org/10.1016/ S0269-7491(00)00180-9 